\title{
Non-Apis bee diversity in an experimental pollinator garden in Bengaluru - a Silicon Valley of India
}

\author{
TM SHIVAlingasWAmY, U AMALA, A GUPTA, A RAGHAVENDRA
}

Division of Germplasm Conservation and Utilization, ICAR-National Bureau of Agricultural Insect Resources, Bengaluru, Karnataka, India

\section{Article History}

\section{Edited by}

Evandro Nascimento Silva, UEFS, Brazil

Received 24 February 2020

Initial acceptance 15 October 2020

Final acceptance 26 October 2020

Publication date 28 December 2020

\section{Keywords}

Bees, Conservation, In-situ, Non-Apis bees, Pollinator garden, Pollen, Shelter.

\section{Corresponding author}

Udayakumar Amala

(iD https://orcid.org/0000-0002-2394-259X

Scientist (Entomology), Division of Germplasm

Conservation and Utilization, ICAR-National

Bureau of Agricultural Insect Resources

H A Farm Post, PB No 2491, Bengaluru

560024, Karnataka, India.

E-Mail: amala.uday@gmail.com

\begin{abstract}
Pollinators are important providers of ecosystem services through plant and crop pollination. However, pollinator population/colony decline has raised concern for their conservation in farm lands as well as in urban areas. Given the need for conservation of these pollinators, we developed a pollinator garden at Yelahanka Campus of ICAR-National Bureau of Agricultural Insect Resources in an area of one acre by planting over 50 plant species. Thirty-nine species of bees were documented from the flora of the pollinator garden. Out of the thirty-nine species of bees, nineteen species of bees belong to non-Apis families viz., Megachilidae and Halictidae. Apart from foraging on the flowers, the solitary bees like Megachile sp. were found nesting in the stems, fallen dried flowers in the pollinator garden. The bees were found year-round foraging upon the flora in the pollinator garden. Pollinator garden is a way to provide in-situ conservation of native bees while sustaining the valuable pollination service in various crop plants.
\end{abstract}

Pollinator insects in agricultural landscapes are dwindling over the years due to the use of agrochemicals, diseases, land fragmentation and rapid urbanization (Biesmeijer et al., 2006; Potts et al., 2010). The intensive agricultural practices make the pollinators and natural enemies devoid of nectar, pollen, shelter, and nesting sites (Cane 2008, Pywell et al., 2011). The easiest and feasible way for conservation of these pollinators could be the maintenance of flora attractive to pollinators such as small patches of pollinator gardens in urban and farmlands, which support them with food and shelter over time. The consequence of such efforts would be the resulting enhancement of pollination service to our food crops. These gardens not only serve as a reservoir of both pollinators and biological control agents like predators and parasitoids but also help in educating the public and enhancing the aesthetic value of the urban and farm ecosystems (Kells et al., 2001; Sheffield et al., 2008). Planting diverse flowering plants in the pollinator garden supports both bee diversity and density in addition to the provision of food and nesting sources for the native bees (Kremen et al., 2002).

An effort has been made to develop two patches (approximately one-acre area) of pollinator gardens in ICARNBAIR-Yelahanka Campus. The campus is spread over 8.5 ha area in the North of Bengaluru city $\left(13^{\circ} 5^{\prime} 48.8724^{\prime}\right.$ ' $\mathrm{N} 77^{\circ}$ 33' 59.7168' E). Over 50 species of plants belonging to diverse families (trees, shrubs, herbs and climbers) were brought from a local state recognized scientific nursery and planted during 2012 and nurtured and observed for their flowering and attractiveness to pollinator insects, especially bees.

We studied forty-six species of plants in the established pollinator gardens. Observations were made on the visitation of different species of bees at 15 days interval over a period of three years (2013-2015). The bees were collected using sweep nets and killed using ethyl acetate. The killed specimens 
were relaxed and dry mounted for taxonomic identification. Some of the bee specimens were identified using taxonomic keys and others were identified by experts whose names are acknowledged in this publication elsewhere. The plant species were ranked into different categories based on the number of bee species attracted (Table 1, Fig 2) The reward (nectar or pollen) and other nest building materials collected by each species of the bees were recorded.
Thirty-nine species of bees were documented from different species of plants maintained in the pollinator garden (Table $2 \&$ Fig 1). The major plant families attracting the bees in the increasing order of attraction were Lamiaceae (Ocimum basilicum and $O$. gratissimum), Convolvulaceae (Argyreia cuneata and Jacquemontia violacea), Acanthaceae (Asystasia gangetica), Asteraceae (Gaillardia pulchella), Passifloraceae (Passiflora edulis) and Lythraceae (Woodfordia fruticosa).
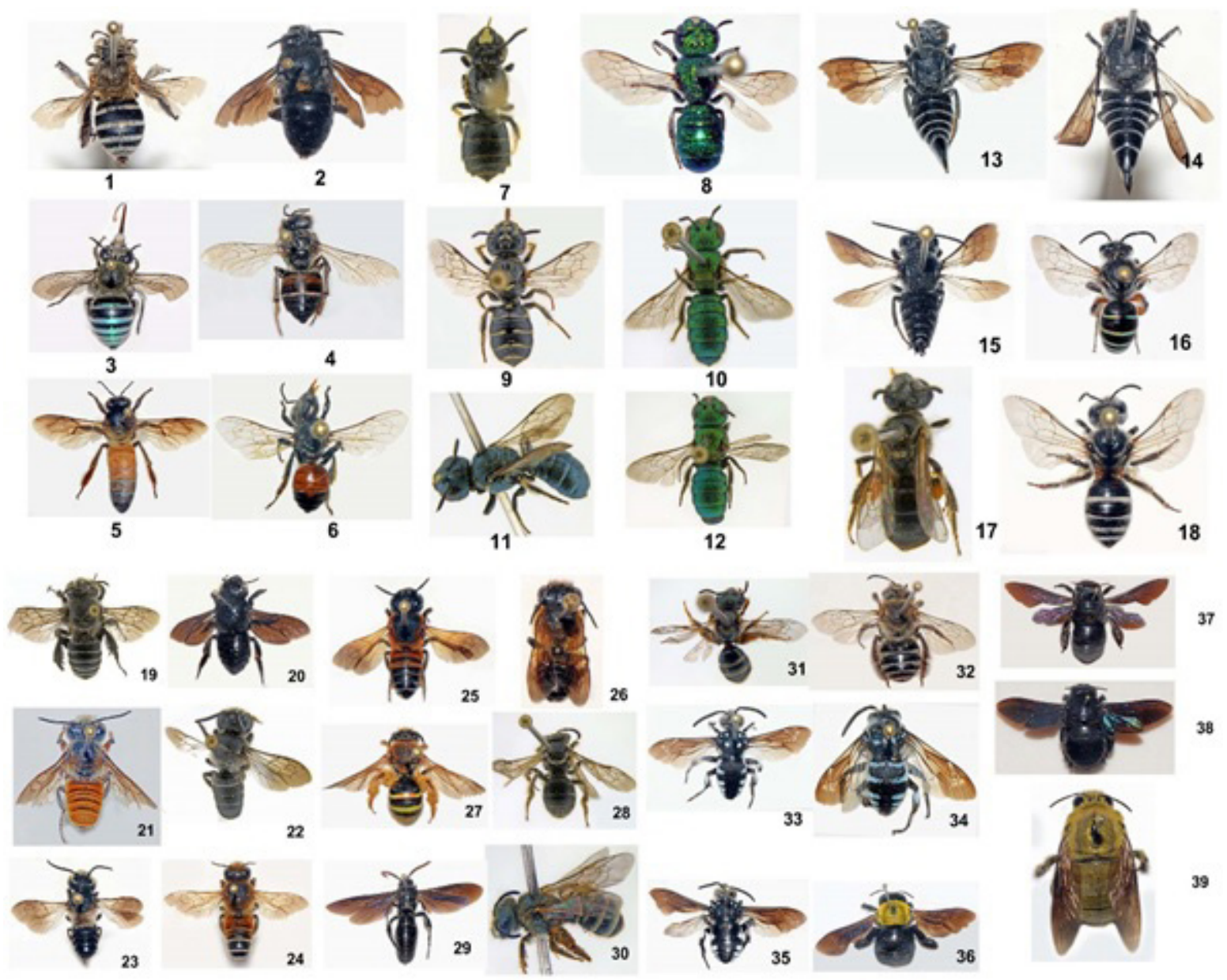

Fig 1. Diverse species of pollinators observed in the pollinator garden.

Argyreia cuneata (Convolvulaceae) was recorded to bloom between April to October, exhibiting attractive purple flowers. The bee activity on this plant was recorded from $0800 \mathrm{hrs}$ to $1500 \mathrm{hrs}$, between May to October. There was a reduction in its population coinciding with the reduction in the blooming of A. cuneata. Tetralonia (Thygatina) macroceps (Anthophorinae: Apidae) was found to forage only on this species. Another congener, Argyreia nervosa, was found to be visited by Xylocopa sp. (Xylocopinae: Apidae) and Lithurgus sp. (Lithurginae: Megachilidae) but not by Tetralonia. The presence and absence of target flora as a determining factor for bee frequencies was reported by Frankie et al. (2009). This behavior shows the floral constancy of the bees. Tetralonia (Thygatina) sp. was reported to prefer the herbaceous plant A. populifolia (Convolvulaceae) (Inoka et al., 2002). Bees belonging to the genus Thyreus were recorded to frequently visit Asystasia gangetica (Acanthaceae). The tubular flowers present in this plant were found to attract long tongued bees as they have typical landing platform for the bees to rest and collect the reward. Carpenter bees belonging to the genus Xylocopa were found to forage on Calotropis gigantea (Apocynaceae), performing nectar robbing activity, a common behavior of carpenter bees according to Zhang et al. (2007).

Woodfordia fruticosa (Lyrthaceae) was found to attract leaf cutting species Megachile anthracina, which was observed employing leaf bits as resources for nest construction. The nectar rich flowers of $W$. fruticosa were found to be actively foraged upon by the little bees Apis florea and A. cerana. Apis florea was found to build its nest in the branches of $W$. fruticosa with the ideal proximity of rich nectar source in the 

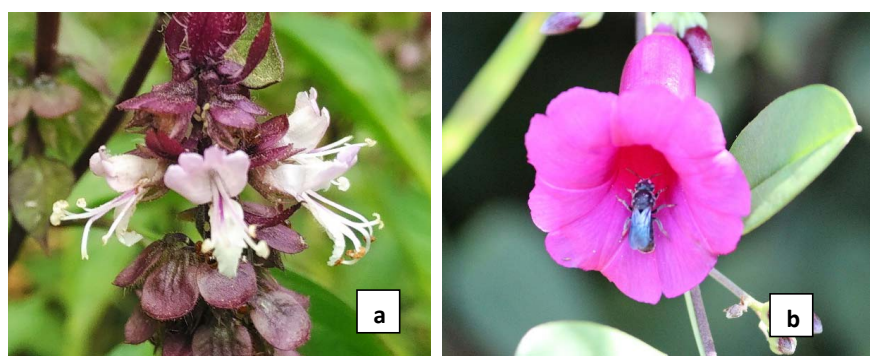

Rank I : a. Ocimum basilicum, b. Argyreia cuneata
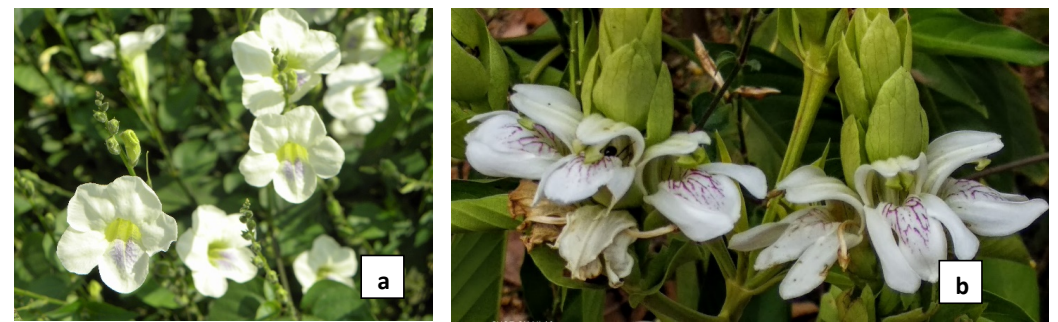

Rank II : a. Asystasia gangetica, b. Adhatoda zeylanica
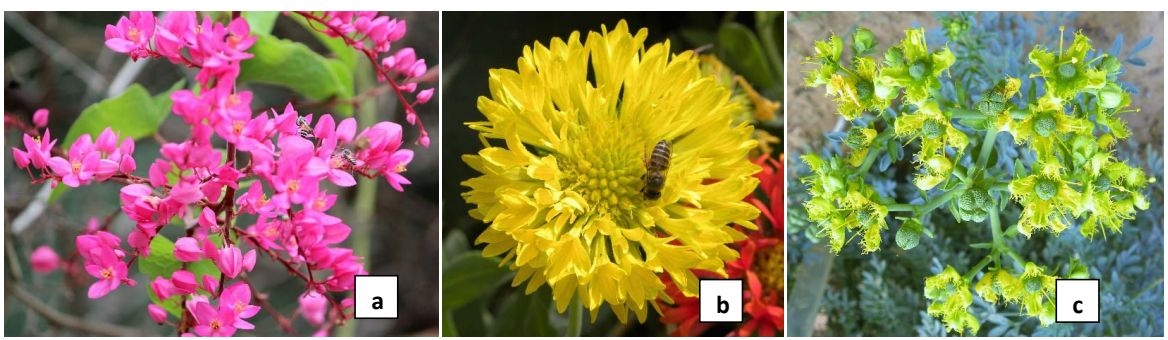

Rank III : a. Antigonon leptopus, b. Gaillardia pulchella, c. Ruta graveolans
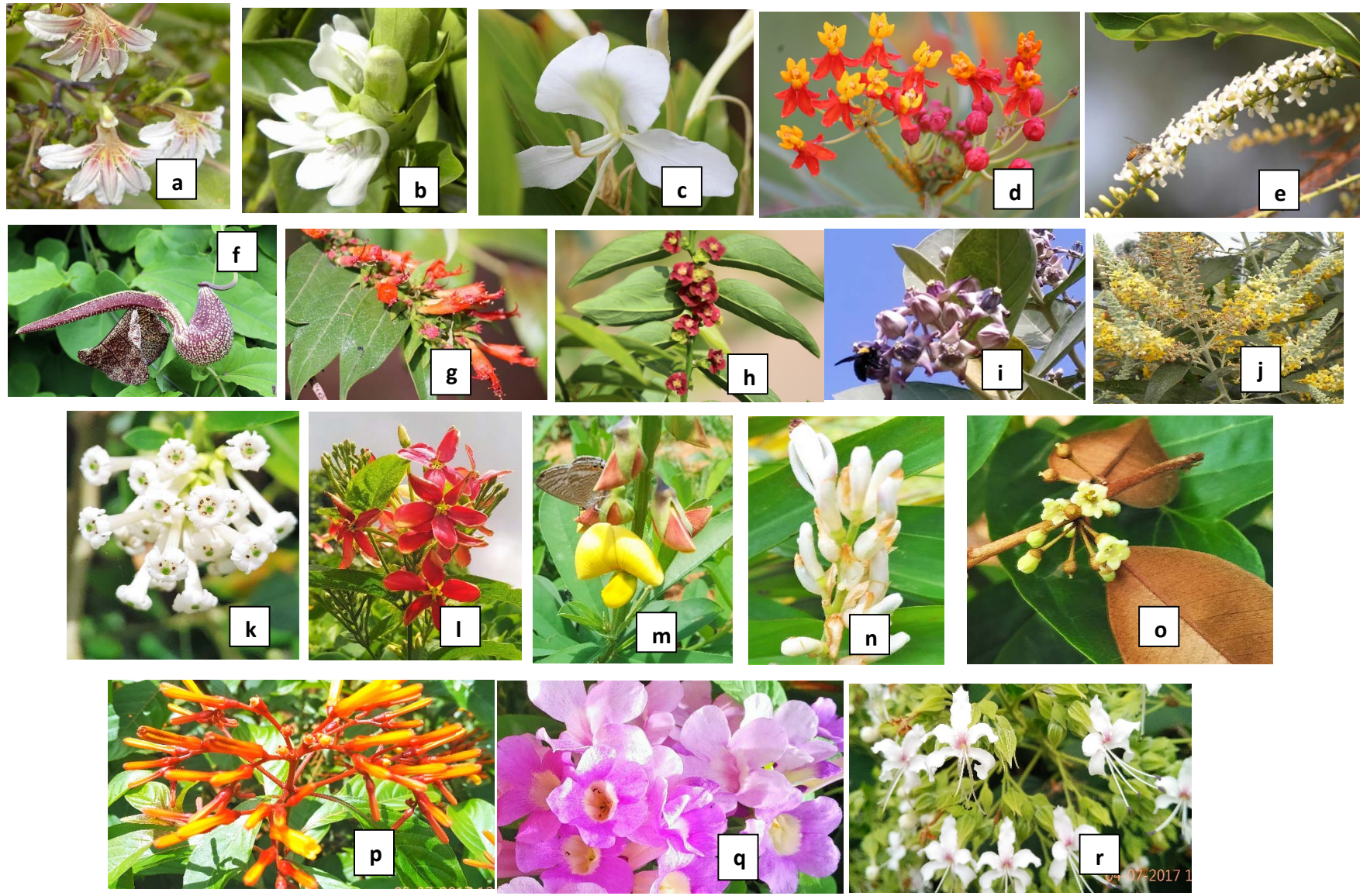

Rank IV: a. Scaveola taccada, b. Adhatoda zeylanica, c. Hedychium coronaria, d. Asclepias curassavica, e. Citharexylum substratum, f. Aristolochia ringens, g. Woodfordia fruticosa, h. Sauropus androgynus, i. Calotropis gigantea, j. Budleja asiática, k. Cestrum diurnum, 1. Quisqualis indica, m. Crotolaria retusa, n. Alpinia sp., o. Chrysophyllum cainito, p. Hamelia patens, q. Mansoa Alliacea, r. Clerodendrum infortunatum

Fig 2. Ranking of plants based on number of bees visited. 
Table 1. Different plant species in the Pollinator garden along with ranking based on the number of bees visited.

\begin{tabular}{|c|c|c|}
\hline Family & Plant Species & Rank \\
\hline Lamiaceae & $\begin{array}{l}\text { Ocimum basilicum* } \\
\text { Ocimum gratissimum } \\
\text { Strobilanthus barbatus } \\
\text { Strobilanthus hamiltoniana }\end{array}$ & I \\
\hline Convolvulaceae & $\begin{array}{l}\text { Argyreia nervosa } \\
\text { Argyreia cuneata* } \\
\text { Ipomoea pescaprae } \\
\text { Jacquemontia violacea }\end{array}$ & I \\
\hline Acanthaceae & $\begin{array}{l}\text { Adhatoda zeylanica } \\
\text { Andrographis paniculata } \\
\text { Asystasia gangetica* }\end{array}$ & II \\
\hline Polygonaceae & Antigonon leptopus* & III \\
\hline Asteraceae & Gaillardia pulchella & III \\
\hline Passifloraceae & Passiflora edulis & III \\
\hline Rutaceae & Ruta graveolans & III \\
\hline Verbenaceae & $\begin{array}{l}\text { Citharexylum substratum } \\
\text { Clerodendrum viscosum* } \\
\text { Vitex negundo }\end{array}$ & IV \\
\hline Elaeocarpaceae & $\begin{array}{l}\text { Elaeocarpus floribundus* } \\
\text { Elaeocarpus sphaericus }\end{array}$ & IV \\
\hline Bignoniaceae & $\begin{array}{l}\text { Mansoa alliacea } \\
\text { Tecoma capensis* }\end{array}$ & IV \\
\hline Solanaceae & $\begin{array}{l}\text { Cestrum diurnum* } \\
\text { Cestrum nocturnum }\end{array}$ & IV \\
\hline Zingiberaceae & Alpinia calcarata & IV \\
\hline Amaranthaceae & Alternanthera sessilis & IV \\
\hline Aristolochiaceae & Aristolochia ringens & IV \\
\hline Annonaceae & $\begin{array}{l}\text { Artabotrys odoratissimus* } \\
\text { Cananga odorata }\end{array}$ & IV \\
\hline Apocynaceae & Asclepias curassavica & IV \\
\hline Plantaginaceae & Bacopa moniera & IV \\
\hline Scrophulariaceae & Budleja asiatica & IV \\
\hline Fabaceae & $\begin{array}{l}\text { Butea monosperma } \\
\text { Crotolaria retusa* }\end{array}$ & IV \\
\hline Apocynaceae & Calotropis gigantea & IV \\
\hline Sapotaceae & Chrysophyllum cainito & IV \\
\hline Vitaceae & Cissus quadrangularis & IV \\
\hline Mimosaceae & Adenanthera pavonina & IV \\
\hline Rubiaceae & Hamelia patens & IV \\
\hline Zingiberaceae & Hedychium coronaria & IV \\
\hline Malpighiaceae & Hiptage benghalensis & IV \\
\hline Lythraceae & $\begin{array}{l}\text { Lagerstromia indica } \\
\text { Woodfordia fruticosa* }\end{array}$ & IV \\
\hline Oleaceae & Nyctanthes arbor-tristes & IV \\
\hline Phyllanthaceae & Sauropus androgynus & IV \\
\hline Goodeniceae & Scaevola taccada & IV \\
\hline Malpighiaceae & Tristellateia australasiae & IV \\
\hline
\end{tabular}

Ranking: I- 15-20 species of bees attracted to the plant, II- 10-15, III- 5-10 and IV-0-5

* The plant species which was more attractive compared with other species in the same families flowers of the plant. The flowers of $W$. fruticosa are a major source of nectar and pollen visited by Apis cerana and $A$. mellifera in Shiwalik hills (Kaur \& Mattu, 2016).

The pithy stems of Clerodendrum viscosum (Verbenaceae) was utilized by small carpenter bee, Ceratina hieroglypica for nest building activity. The destructive sampling of $C$. viscosum revealed the brood nests of the small carpenter bee C. hieroglyphica harbouring its life stages of pollen food. Pithy stems of Caesalpinia pulcherrima after pruning the branches were reported to be natural nesting sites of small carpenter bee, C. binghami (Amala \& Shivalingaswamy, 2019). Continuous availability of flowers in the pollinator garden was found to sustain different species of bees from Spring to Summer. Plants like Asystasia sp. (Acanthaceae) and Hamelia patens (Rubiaceae) were found to have long blooming periods supporting the bee fauna with pollen and nectar rewards. Similar observations were recorded by Wojcik et al. (2008) and reported that flowers with long blooming periods sustained different species of bees in a seasonal sequence. The plant Tristellateia australasiae (Malpighiaceae) was found to be foraged upon by little bee A. florea in large numbers. The composite flowers of Gaillardia pulchella (Asteraceae) was found to be foraged by different species of halictid bees viz., Nomia curvipes, Seladonia propinqua in search for pollen. Blue banded bees Amegilla zonata (Anthphorinae: Apidae) and Sweat bees Hoplonomia westwoodi (Nominae: Halictidae) were recorded as some of the buzz pollinators of tomato and eggplant present in the pollinator garden.

Six different aromatic plants belonging to the family Lamiaceae were reported to attract and support many species of bees and hover flies (Barbir et al., 2016). Raju (2005) reported that three species of bees viz., Apis cerana indica, Trigona iridipennis and Ceratina simillima visited the flowers of Woodfordia floribunda Salisb. (Lythraceae) for the collection of pollen and nectar. Plants belonging to the family Convolvulaceae viz., Argyreia populifolia, Ipomoea cairica, I. mauritiana and I. pescaprae attracted five species of solitary bees Lithurgus atratus, Lasioglossum halictoides, L. serenum, Systropha tropicalis and Tetralonia sp.1 in Sri Lanka (Karunaratne et al., 2005). The flowers of the family Asteraceae with typical daisy like flower was reported to attract solitary bees, hoverflies, and 'other' flower-visiting insects (Rollings \& Goulson, 2019). Peters (2014) reported that Trigona fulviventris, Halictids, Ceratina sp and Bombus pullatus visited the flowers of Hamelia patens (Rubiaceae) for pollen and nectar collection. The flowers of plant, Asystasia chelonoides (Acanthaceae) were reported to be visited by four different species of bees viz., Amegilla comberi, A. puttalama, A. scintillans and Apis cerana (Karunaratne et al., 2005). Xylocopa latipes and X. pubescens as a floral visitor and pollinator of Calotropis gigantea and C. procera was reported by Zafar et al. (2018).

Holistically, the plants and the flora in the pollinator garden were found to attract a diverse assemblage of bee 
Table 2. Non-Apis bee and scolid wasp species recorded in the pollinator garden.

\begin{tabular}{|c|c|c|}
\hline S. No. & Bee species & Family \\
\hline 1 & Amegilla confusa (Smith, 1854) & Apidae \\
\hline 2 & Amegilla violacea (Lepeletier, 1841) & Apidae \\
\hline 3 & Amegilla sp. (zonata group): & Apidae \\
\hline 4 & Apis cerana Fabricius, 1793 & Apidae \\
\hline 5 & Apis dorsata Fabricius, 1793 & Apidae \\
\hline 6 & Apis florea Fabricius, 1787 & Apidae \\
\hline 7 & Braunsapis sp. & Halictidae \\
\hline 8 & Ceratina binghami Cockerell, 1908 & Apidae \\
\hline 9 & Ceratina hieroglyphica Smith, 1854 & Apidae \\
\hline 10 & Ceratina smaragdula (Fabricius, 1787) & Apidae \\
\hline 11 & Ceratina sp.1 & Apidae \\
\hline 12 & Ceratina sp.2 & Apidae \\
\hline 13 & Coelioxys basalis Smith, 1875 & Megachilidae \\
\hline 14 & Coelioxys confusus Smith, 1854 & Megachilidae \\
\hline 15 & Coelioxys sp. & Megachilidae \\
\hline 16 & Hoplonomia westwoodi (Gribodo, 1894) & Halictidae \\
\hline 17 & Lasioglossum (Ctenonomia) sp. 1 & Halictidae \\
\hline 18 & Lasioglossum sp. 2 & Halictidae \\
\hline 19 & Lithurgus atratus Smith, 1853 & Megachilidae \\
\hline 20 & Megachile anthracina Smith, 1853 & Megachilidae \\
\hline 21 & Megachile bicolor (Fabricius, 1781) & Megachilidae \\
\hline 22 & Megachile cephalotes Smith, 1853 & Megachilidae \\
\hline 23 & Megachile disjuncta (Fabricius, 1781) & Megachilidae \\
\hline 24 & Megachile lanata (Fabricius, 1775) & Megachilidae \\
\hline 25 & Megachile sp.1 & Megachilidae \\
\hline 26 & Megachile sp.2 & Megachilidae \\
\hline 27 & Nomia curvipes (Fabricius, 1793) & Halictidae \\
\hline 28 & Pachynomia sp. & Halictidae \\
\hline 29 & Scolia affinis Guérin-Méneville, 1830 & Halictidae \\
\hline 30 & Seladonia propinqua (Smith, 1853) & Halictidae \\
\hline 31 & Seladonia sp. & Halictidae \\
\hline 32 & $\begin{array}{l}\text { Tetralonia (Thygatina) macroceps } \\
\text { (Engel \& Baker,2006) }\end{array}$ & Apidae \\
\hline 33 & Thyreus histrio (Fabricius, 1775) & Apidae \\
\hline 34 & Thyreus massuri (Radoszkowski, 1893) & Apidae \\
\hline 35 & Thyreus sp. & Apidae \\
\hline 36 & Xylocopa aestuans (Linnaeus, 1758) & Apidae \\
\hline 37 & Xylocopa amethystina (Fabricius, 1793) & Apidae \\
\hline 38 & Xylocopa latipes (Drury, 1773) & Apidae \\
\hline 39 & Xylocopa sp. & Apidae \\
\hline
\end{tabular}

species belonging to the families Apidae, Megachilidae, and Halictidae. Plants belonging to the family Lamiaceae and Convolvulaceae could be ideally used to conserve native Apis/ non-Apis bees. The concept of pollinator garden is a vital tool to conserve the native pollinators by providing them food source (nectar and pollen) and habitat (nests construction). Pollinator gardens could be encouraged in urban habitats to enhance the aesthetic value, educative tool for school children and finally to sustain the ecosystem services provided by the pollinators.

\section{Acknowledgements}

The authors are thankful to Dr. C. A. Viraktamath, Emeritus Professor, Principal Investigator, ICAR Network Project on Biosystematics, University of Agricultural Sciences, GKVK Bangalore. Dr. K. D. Prathapan, Professor, KAU, Thiruvananthapuram for confirmation of a specific bee encountered on Argyreia cuneata as Tetralonia (Thygatina) macroceps. We thank Dr. Chandish R Ballal, Director, ICARNBAIR for her constant support and encouragement in our efforts in conservation of pollinators.

\section{Authors' contribution}

TMS conceptualized and coordinated the conduct of the study. AG identified the bee specimens. AR assisted in recording field observations. UA analyzed the data and drafted the manuscript. All authors have read and approved the manuscript.

\section{References}

Barbir, J., Azpiazu, F.R.B., Fernandez-Quintanilla, C. \& Dorado, J. (2016). Functionality of selected aromatic Lamiaceae in attracting pollinators in Central Spain. Journal of Economic Entomology, 109: 529-536.

Biesmeijer, J., Roberts, S.P.M., Reemer, M., Ohlemuller, R., Edwards, T.M.J., Peeters, M., Schaffers, A.P., Potts, S.G., Kleukers, R.J.M.C., Thomas, C., Settele, J. \& Kunin, W. (2006). Parallel declines in pollinators and insect-pollinated plants in Britain and the Netherlands. Science, 313: 351-354.

Cane, J.H. (2008). A native ground-nesting bee (Nomia melanderi) sustainably managed to pollinate alfalfa across an intensively agricultural landscape. Apidologie, 39: 315-323.

Frankie, G.W., Thorp, R.W., Hernandez, J., Rizzardi, M., Ertter, B., Pawelek, J.C., Witt, S.L., Schindler, M., Coville, R. \& Wojcik. V.A. (2009). Native bees are a rich natural resource in urban California gardens. California Agriculture, 63: 113-120.

Frankie, G.W.M., Rizzardi, M., Vinson, S.B. \& Griswold, T.L. (2009). Decline in bee diversity and abundance from 1972-2004 on a flowering leguminous tree, Andira inermis in Costa Rica at the interface of disturbed dry forest and the urban environment. Journal of the Kansas Entomological Society, 82: 1-20.

Inoka, W.A., Karunaratne, P. \& Edirisinghe, J.P. (2002). Bee diversity and floral hosts in selected habitats of the Peradeniya University park. Ceylon Journal of Science, 30: 21-36.

Inoka, W.A., Karunaratne, P., Edirisinghe, J.P. \& Gunatillieke, C.V.S. (2005). Floral relationships of bees in selected areas of Sri Lanka. Ceylon Journal of Science 34: 27-45. 
Kells, A., Holland, J. \& Goulson, D. (2001) The value of uncropped field margins for foraging bumblebees. Journal of Insect Conservation, 5: 283-291.

Kremen, C., Williams, N.M. \& Thorp, R.W. (2002). Crop pollination from native bees at risk from agricultural intensification. Proceedings of the National Academy of Sciences of the United States of America, 99: 16812-16816.

Peters, V.E. (2014). Intercropping with shrub species that display a 'Steady state' flowering phenology as a strategy for biodiversity conservation in tropical agroecosystems. Plos One, 9: e90510.

Potts, S.G., Biesmeijer, J.C., Kremen, C., Neumann, P., Schweiger, O. \& Kunin, W.E. (2010). Global pollinator declines: trends, impacts and drivers. Trends in Ecology and Evolution, 25: 345-353.

Pywell, R.F., Meek, W.R., Hulmes, L., Hulmes, S., James, K. L., Nowakowski, M. \& Carvell, C. (2011). Management to enhance pollen and nectar resources for bumblebees and butterflies within intensively farmed landscapes. Journal of Insect Conservation, 15: 853-864.

Raju, A.J.S. (2005). Passerine bird pollination and seed dispersal in Woodfordia floribunda Salisb. (Lythraceae), a common low altitude woody shrub in the Eastern Ghats forests of India. Ornithological Science, 4: 103-108.

Rollings, R. \& Goulson, D. (2019). Quantifying the attractiveness of garden flowers for pollinators. Journal of Insect Conservation, 23:803-817.

Sheffield, C.S., Westby, S.M., Smith, R.F. \& Kevan, P.G. (2008). Potential of bigleaf lupine for building and sustaining Osmia lignaria populations for pollination of apple. The Canadian Entomologist, 140: 589-599.

Wojcik, V.A., Frankie, G.W., Thorp, R.W. \& Hernandez, J. (2008). Seasonality in bees and their floral resource plants at a constructed urban bee habitat in Berkeley, California. Journal of the Kansas Entomological Society, 81: 15-28.

Zafar, R., Raju A.J.S. \& Kumar, B.D. (2018). Floral biology and carpenter bee pollination in Calotropis gigantea and Calotropis procera (Asclepiadeceae). Journal of Palynology, 54: 85-99.

Zhang, Y.W., Robert, G.W., Wang, Y. \& Guo, Y. H. (2007). Nectar robbing of a carpenter bee and its effects on the reproductive fitness of Glechoma longituba (Lamiaceae). Plant Ecology, 193: 1-13. 